\title{
Hydrogeologic Data from Selected Wells and Test Holes In and Adjacent to the Nevada Test Site, Nye County, Nevada, Through 1986
}

By Freddy E. Arteaga, Charles S. Savard,

Michael E. Johnson, and J. Christopher Stone

U.S. GEOLOGICAL SURVEY

Open-File Report 87-536

Prepared in cooperation with the NEVADA OPERATIONS OFFICE, U.S. DEPARTMENT OF ENERGY

Interagency Agreement DE-AI08-86-NV10583

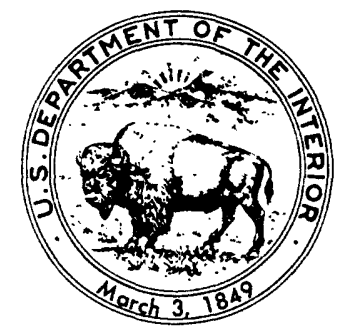

Carson City, Nevada 1991 


\title{
DEPARTMENT OF THE INTERIOR
}

\author{
MANUEL LUJAN, JR., Secretary
}

\section{U.S. GEOLOGICAL SURVEY}

\author{
Dallas L. Peck, Director
}

\footnotetext{
Any use of trade, product, or firm names in this publication is for descriptive purposes only and does not constitute endorsement by the U.S. Government.
}

For additional information write to:

\section{U.S. Geological Survey}

Room 227, Federal Building

705 North Plaza Street

Carson City, NV 89701
Copies of this report may be purchased from:

U.S. Geological Survey

Books and Open-File Reports Section Federal Center, Building 810

Box 25425

Denver, CO 80225 
ABSTRACT -

INTRODUCTION -

DATA SOURCE -

ACKNOWLEDGMENTS -

MAP INFORMATION

TABLE EXPLANATION

Map-index number

Well and test-hole designation

Latitude and longitude

Construction data

Land-surface altitude -

Ground-water level data

Lithology and geologic unit code

Reference list -

REFERENCES CITED -

BASIC DATA

\section{IILUSTRATION}

(Plate is in pocket at back of report)

Plate 1. Map showing location of selected wells and test holes

TABLE

Table 1. Hydrogeologic data for selected wells and test holes ---

\section{CONVERSION FACTORS AND ABBREVIATIONS}

"Inch-pound" units of measure used in this report may be converted to metric (International System) by using the following factors:

Multiply

Foot (ft)

Inch (in.)

Mile (mi)

$$
\text { By }
$$

0.3048
25.40
1.609

To obtain

Meter (m) Millimeter ( $\mathrm{mm})$ Kilometer ( $\mathrm{km})$

SEA LEVEL

In this report, "sea level" refers to the National Geodetic Vertical Datum of 1929 (NGVD of 1929, formerly called "Sea-Level Datum of 1929"), which is derived from a general adjustment of the first-order leveling networks of both the United States and Canada. 


\title{
HYDROGEOLOGIC DATA FROM SELECTED WELLS AND TEST HOLES IN AND ADJACENT TO THE NEVADA TEST SITE, NYE COUNTY, NEVADA, THROUGH 1986
}

\author{
By Freddy E. Arteaga, Charles S. Savard, \\ Michael E. Johnson, and J. Christopher Stone
}

\begin{abstract}
Hydrogeologic data collected from selected wells and test holes in the Nevada Test Site area show that the measured depth to water in the area ranged from 92 to 2,467 feet below land surface. The measured altitude of the ground-water surface ranged from 2,289 to 5,913 feet above sea level. Ground water in the Nevada Test Site area is present in three major types of rocks: Quaternary sediments, Tertiary volcanics, and Paleozoic sedimentary and minor intrusive rocks.

The hydrogeologic data were collected from wells and test holes ranging from 261 to 13,686 feet deep. The casing size ranged from 1.2-inch diameter in exploratory holes to 122-inch diameter in emplacement holes. Detailed geologic descriptions, selected borehole geophysical logs, aquifer-test data, and water-quality data for many of the wells and test holes can be obtained from published reports.
\end{abstract}

\section{INTRODUCTION}

An understanding of the ground-water hydrology in the area of the Nevada Test Site (NTS) is necessary for the safe and economical operation of the NTS facility. Since the early 1950's, the U.S. Geological Survey, in cooperation with the U.S. Atomic Energy Commission (now the U.S. Department of Energy), has studied the ground-water hydrology and the geology of the NTS area. Hydrogeologic data collected by the U.S. Geological survey and other governmental agencies and private contractors are being compiled for input to a computerized data base. This report contains location, construction, water-level, and geologic data for selected wells and test holes in the NTS area. Users of this report will find summarized information listed in table 1. Detailed information can be obtained from published reports listed in the "References Cited" section.

Several data bases supported by national laboratories and the U.S. Geological Survey incorporate water level, geology, geophysical, geomechanical, and water-quality data for the NTS. Data included in this report are being stored in the Ground Water Site Inventory (GWSI) data base. This computerized data base is maintained by the U.S. Geological Survey as a national repository for ground-water information. The information stored in this data base has been screened carefully and may be retrieved in several different formats. The Nevada District office of the U.S. Geological Survey, Water Resources Division, may be contacted for additional information regarding retrieval of these data. 
Ground-water data presented in this report are limited to selected well and test-hole data collected within the boundaries of NTS, selected data from exploratory holes used by the Nevada Nuclear waste Storage Investigation program (NNWSI), and data from several holes in other areas adjacent to the NTS. Well and test-hole locations are shown on plate 1 .

A detailed description of the ground-water hydrology in the area of NTS is presented in Blankennagel and Weir (1973), Waddell (1982), Waddell and others (1984), and Winograd and Thordarson (1975).

\section{DATA SOURCE}

Computerized data bases, published and unpublished reports, and U.S. Geological Survey data files were used to compile the information on the 187 wells and test holes listed in this report. The unpublished reports and files are located in the U.S. Geological survey offices in Mercury and Las Vegas, Nev., and Denver, Colo.

Locations of the wells and test holes were obtained from the Lawrence Livermore National Laboratory (LLNL) data base (Howard, 1976, 1983) and construction data were obtained from Fenix \& Scisson, Inc., data files located in Mercury, Nev. Data for several test holes and wells drilled prior to 1960 were obtained from Thordarson and others (1967).

Water-level data were compiled from published reports, LLNL data base, and U.S. Geological Survey data files. The LLNL data base contains many water-level measurements that are not representative of the natural groundwater flow system. These nonrepresentative water levels, perhaps, resulted from the techniques used in the construction of the hole. Therefore, they reflect physical conditions in the hole at the time of the measurement, and may not represent the true static water levels in the surrounding rocks. These data have been screened to retain only representative static water levels; however, additional information could cause a reinterpretation of the static water level from field data. Any changes resulting from the reinterpretations will be entered into the GWSI data base.

The geologic data were obtained from published reports of the U.S. Geological Survey, Geologic Division, and from a U.S. Geological Survey geologic data base described by Williams (1986). Only the saturated portions of the hole are addressed in this report. The GWSI data base, however, contains geologic data for the entire hole.

\section{ACKNOWLEDGMENTS}

Substantial contributions, including field inventories of water wells and other hydrologic work, were made by consulting firms that were, at the time, under contract with the U.S. Department of Energy. These include: Holmes \& Narver, Inc.; Fenix \& Scisson, Inc.; and Birdwell, Inc. Data also were provided by Lawrence Livermore National Laboratory, Los Alamos National Laboratory, and Sandia National Laboratory. In addition, Evan C. Jenkins and Paul P. Orkild of the U.S. Geological Survey, Geologic Division, furnished geologic data from their files. The authors also are indebted to Jefferson D. Hanson and Glenn Jablin for assistance in preparing the reference list. 


\section{MAP INFORMATION}

Plate 1 presents the well or test-hole location and the assigned index number. The NTS administrative areas are also outlined on the map. Waterlevel contour maps are available in reports by Blankennagel and Weir (1973), Doty and Thordarson (1983), Waddell and others (1984), and winograd and Thordarson (1975).

\section{TABLE EXPLANATION}

\section{Map Index Number}

Each well and test hole has been assigned an index number for cross-referencing plate 1 and table 1 . The hydrogeologic data listed in table 1 are grouped according to the administrative areas of the NTS. Wells and test-holes located outside the NTS boundary are listed at the end of table 1 .

\section{Well and Test-Hole Designation}

Wells and test holes are assigned a designation according to the type of hole drilled, area drilled in, and the sequence code for the consecutive order that the hole was drilled or redrilled. Emplacement holes begin with the letter "U," followed by the NTS area number and the sequence code letter. Sometimes the drilling of a hole is abandoned and a nearby location is used. The letter "S" is then added to the sequence designation to indicate a substitute hole. An example is "U19as," which is an emplacement hole in area 19 with the sequence code " $a$ " and an "S" to indicate that the original hole was abandoned but a substitute hole was completed. Exploratory holes follow the same designation procedure, but begin with "UE." Thus, "UEla" is an exploratory hole in area 1 with a sequence code of "a."

Post-shot holes are designated to associate them with the appropriate emplacement hole. The emplacement-hole designation is used with the addition of "PS" and another sequence code for the post-shot holes associated with the particular emplacement hole. For example, "U20nPSIDDH" is a postshot hole associated with the "U20n" emplacement hole, and has a sequence code of "IDDH." Holes instrumented for nuclear testing are designated to associate them with the appropriate emplacement hole. Thus, "U19ab-2" is the number-two instrumented hole associated with emplacement hole "U19ab."

Other holes are designated according to the associated projects. "RNM-1" is a hole used for radionuclide migration studies. "Pahute Mesa No. 2" is a hole drilled for exploration purposes on Pahute Mesa.

Wells are designated as either test wells or water wells. "Well C-1" is a water well in area 6. Test wells and test holes have been drilled for exploration purposes and are designated appropriately. Holes drilled southwest of NTS in support of NNWSI objectives are prefixed with a "USW." 


\section{Latitude and Longitude}

The latitude and longitude of the wells and test holes are given in degrees, minutes, and seconds. Rounding procedures used for presentation of latitude and longitude reduce the accuracy to \pm 1 second. The well and test-hole locations are surveyed to a greater degree of accuracy than can be recorded with latitude and longitude coordinates. Accurate locations of up to 1 foot, based on the Nevada coordinate system, can be found in Fenix \& Scisson, Inc., data files.

\section{Construction Data}

The construction data listed in table 1 include the date the well or test hole was completed, depth drilled, and diameter and depth of casing. The diameter of the casing refers to the inside diameter for emplacement holes, and the outside diameter for all others. The completion date is in month and year. The depth drilled and casing depth are in feet below land surface.

Casing in the emplacement holes may have diameters of up to 122 inches. Casing in wells and exploratory holes diameters generally range from 2.9 to 20 inches. The deepest hole drilled, "UE20f," is 13,686 feet below land surface. The deepest casing has been set to 7,543 feet below land surface in "Pahute Mesa No. 1."

\section{Land-Surface Altitude}

The surveyed land-surface altitude for each well or test hole is reported to the nearest foot. Land-surface altitudes for wells and test holes range from 3,081 to 7,573 feet above sea level. Holes "U12e03-1" and "U12eMl" were drilled in a tunnel complex. The land-surface altitude for these two holes is the altitude of the tunnel floor.

\section{Ground-Water Level Data}

The ground-water level data contained in this report are depth to water, date measured, water-surface altitude, and source of the measurement. The depth to water is the distance to water, in feet, measured below the land surface. For holes used as production wells, measurements were taken after the well had been shut off for a period of time. All water-level measurements are rounded to the nearest foot. In wells tapping more than one aquifer, the water level listed is considered to be a composite of the static level of each aquifer penetrated.

For water-levels with the source designated as "USGS," the measurements were obtained by a steel tape or iron horse. Garber and Koopman (1968) and Weir and Nelson (1976) describe the field measurement techniques used. Water-level measurements with the source designated as "BFDL" were obtained from fluid density logs taken by Birdwell, Inc., as reported in the LLNL data base. Water-level measurements with the source designated as "BWL" were obtained by means of water locater tools by Birdwell, Inc., as reported in the LLNL data base. Water levels for "UE5j," "UE5k," and "UE5m" did not have an identifiable source, but are contained in the LLNL data base. 
Depth-to-water measurements ranged from 92 to 2,467 feet below land surface. Water-surface altitudes ranged from 2,289 to 5,913 feet above sea level. The water-level measurement dates range from 1959 to 1986 . Some wells have more than one depth-to-water measurement, but no measurements since 1986 are reported in table 1.

Water-level values marked with ">" are from wells and test holes where the water-level measurements were not representative of static conditions because mud or water used during the drilling process was still present in the hole at the time of the measurement. Time constraints of the drilling program did not allow fluid levels to stabilize.

\section{Lithology and Geologic Unit code}

The lithology of the saturated portion of the hole was taken from published material and U.S. Geological Survey data files. Abbreviations used in table 1 are standard GWSI terminology. The three major types of saturated material found at NTS are Quaternary sediments, Tertiary volcanics, and Paleozoic sedimentary rocks. Minor intrusive rocks also occur in several parts of NTS and are saturated at depth. During the drilling of "UE20f" on Pahute Mesa, more than 13,000 feet of Tertiary volcanic rocks were penetrated.

Geologic unit codes, used in GWSI, are listed for each hole. For many of the holes completed in the Tertiary volcanics, either detailed stratigraphic information is unavailable or geologic unit codes have not been assigned for particular units. These holes use the overall geologic unit code "120vLCC" which stands for Tertiary volcanic rocks. Stratigraphic data for some of the holes finished in the Paleozoic sedimentary carbonates do not differentiate between the different units. The geologic unit code for these holes is "300CRBN." Detailed information on the thickness of individual geologic units can be found in the referenced reports.

\section{Reference list}

References listed in table 1 include selected published U.S. Geological Survey reports that contain comprehensive information on well construction, geologic formations penetrated, well-pumping tests, geophysical logs, waterquality analyses, and other related hydrogeologic data. Most of the formation-property logs (including caliper, resistivity, density, velocity, and magnetometer logs) are stored routinely in the Geophysical Data System, maintained by the Lawrence Livermore National Laboratory. 
1. Benson, L.V., Robison, J.H., Blankennagel, R.K., and Ogard, A.E., 1983, Chemical composition of ground water and the locations of permeable zones in the Yucca Mountain Area, Nevada:

U.S. Geological Survey Open-File Report 83-854, 19 p.

2. Bentley, C.B., 1984, Geohydrologic data for Test Well USW G-4 Yucca Mountain area, Nye County, Nevada: U.S. Geological Survey Open-File Report $84-063,48 \mathrm{p}$.

3. Bentley, C.B., Robison, J.H., and Spengler, R.W., 1983, Geohydrologic data for Test Well USW H-5, Yucca Mountain area, Nye County, Nevada: U.S. Geological Survey Open-File Report 83-853, 34 p.

4. Blankennagel, R.K., 1967, Hydraulic testing techniques of deep drill holes at Pahute Mesa, Nevada Test Site: U.S. Geological Survey open-File Report, $50 \mathrm{p}$.

5. Blankennagel, R.K., and Weir, J.E., Jr., 1973, Geohydrology of the eastern part of Pahute Mesa, Nevada Test Site, Nye County, Nevada: U.S. Geological Survey Professional Paper $712-\mathrm{B}, 35 \mathrm{p}$.

6. Byers, F.M., Jr., and Hawkins, W.L., 1981, Geology of drill hole UE18t and area 18, Timber Mountain caldera moat, Nevada Test Site, with a section on Geophysical logging by D.C. Muller: U.S. Geological Survey Report USGS-474-312, $69 \mathrm{p}$. Available only from National Technical Information Service, U.S. Department of Commerce, Springfield, VA 22161.

7. Carr, W.J., Byers, F.M., Jr., and Jenkins, E.C., 1981, Geology of drill hole UE18r, Timber Mountain Caldera, Nevada Test Site: U.S. Geological Survey Report USGS-474-313, 23 p. Available only from National Technical Information Service, U.S. Department of Commerce, Springfield, VA 22161.

8. Claassen, H.C., 1973, watex quality and physical characteristics of Nevada Test Site water-supply wells: U.S. Geological Survey Report USGS-474-158, $145 \mathrm{p}$. Available only from National Technical Information Service, U.S. Department of Commerce, Springfield, VA 22161.

9. Craig, R.W., and Johnson, K.A., 1984, Geohydrologic data for Test Well UE-25p\#1, Yucca Mountain area, Nye County, Nevada: U.S. Geological Survey Open-File Report 84-450, $63 \mathrm{p}$.

10. Craig, R.W., Reed, R.L., and Spengler, R.W., 1983, Geohydrologic data for Test Well USW H-6 Yucca Mountain area, Nye County, Nevada: U.S. Geological Survey Open-File Report 83-856, 35 p.

11. Craig, R.W., and Robison, J.H., 1984, Geohydrology of rocks penetrated by Test Well UE-25p\#1 Yucca Mountain Area, Nye County, Nevada: U.S. Geological Survey Water-Resources Investigations Report $84-4248,57 \mathrm{p}$.

12. Dinwiddie, G.A., and Weir, J.E., Jr., 1979, Summary of hydraulic tests and hydrologic data for holes UEl6d and UE16f, Syncline Ridge area, Nevada Test Site: U.S. Geological Survey Report USGS-1543-3, 25 p. Available only from National Technical Information Service, U.S. Department of Commerce, springfield, VA 22161. 
13. Dixon, G.L., Quinlivan, W.D., Ray, J.M., and Ohl, J.P., 1975, Supplementary lithologic logs and stratigraphic identifications for exploratory and emplacement drill holes in areas 3,4 , and 7 , Nevada Test Site: U.S. Geological Survey Report USGS-474-211, 87 p. Available only from National Technical Information Service, U.S. Department of Commerce, Springfield, VA 22161.

14. Doty, G.C., and Thordarson, William, 1983, Water table in rocks of Cenozoic and Paleozoic age, 1980, Yucca Flat, Nevada Test Site, Nevada: U.S. Geological Survey Water-Resources Investigations Report 83-4067, 1 sheet.

15. Ellis, W.L., and Swolfs, H.S., 1983, Preliminary assessment of in-situ geomechanical characteristics in drill hole USW G-1, Yucca Mountain, Nevada: U.S. Geological Survey Open-File Report 83-401, 18 p.

16. Garber, M.S., 1971, Hydraulic-test and quality-of-water data from hole U-3cn PS\#2, Bilby Site, Nevada Test Site: U.S. Geological Survey Report USGS-474-105, 81 p. Available only from National Technical Information Service, U.S. Department of Commerce, Springfield, VA 22161 .

17. Garber, M.S., and Koopman, F.C., 1968, Methods of measuring water levels in deep wells: U.S. Geological Survey Techniques of Water-Resources Investigations, Book 8, Chapter A1, 23 p.

18. Garber, M.S., and Thordarson, William, 1962, Ground water Test Well C, Nevada Test Site, Nye County, Nevada: U.S. Geological Survey Open-File Report TEI-818, 79 p.

19. Gonzalez, D.D., Warren, C.T., and Washington, C.L., 1973, water levels and spring discharges for selected wells and springs in Nevada, 1966-69: U.S. Geological Survey Report USGS-474-171, 69 p. Available only from National Technical Information Service, U.S. Department of Commerce, Springfield, VA 22161.

20. Hood, J.W., 1964, Water wells in Frenchman and Yucca Valleys, Nevada Test Site, Nye County, Nevada: U.S. Geological Survey Open-File Report TEI-788, 59 p.

21. Hoover, D.L., 1972, Geology of the U12e.06 UG-1 drill hole, area 12, Nevada Test Site: U.S. Geological Survey Open-File Report 12-31, $17 \mathrm{p}$.

22. Houser, F.N., and Poole, F.G., 1959a, "Granite" exploration hole, area 15, Nevada Test Site, Nye County, Nevada--Interim Report, Part A, structural, petrographic, and chemical data: U.S. Geological Survey Open-File Report USGS-TEM-836, 58 p.

23. -- 1959b, Lithilogic $\log$ and drilling information for the Marble Exploration Hole 3, U15 Area, Nevada Test Site, Nye County, Nevada: U.S. Geological Survey Open-File Report TEM-1031, 22 p.

24. Howard, N.W., 1976, The Lawrence Livermore Laboratory nuclear test effects and geologic data bank: Lawrence Livermore National Laboratory, Preprint UCRL-78799, $20 \mathrm{p}$.

25. ---1983, LINL containment program nuclear test effects and geologic data base--glossary and parameter definitions: Lawrence Livermore National Laboratory, UCID-18300, part 1, revision 1, 88 p. 
26. Izett, G.A., 1960, "Granite" exploration hole, area 15, Nevada Test Site, Nye County, Nevada--Interim Report, Part C, physical properties: U.S. Geological Survey Open-File Report USGS-TEM-836-C, $37 \mathrm{p}$.

27. Jenkins, C.E., 1969, Summary geologic report on the UE20p exploratory hole, area 20, Pahute Mesa, Nevada Test Site: U.S. Geological Survey Report USGS-474-15, 20 p. Available only from National Technical Information Service, U.S. Department of Commerce, Springfield, VA 22161.

28. ----1970, Revised lithologic log of Pahute Mesa Exploratory Drill Hole No. 1, Nevada Test Site: U.S. Geological Survey Report USGS-474-96, 8 p. Available only from National Technical Information Service, U.S. Department of Commerce, Springfield, VA 22161.

29. Lahoud, R.G., Lobmeyer, D.H., and Whitfield, M.S., Jr., 1984, Geohydrology of volcanic tuff penetrated by Test well UE-25b\#1, Yucca Mountain, Nye County, Nevada: U.S. Geological Survey WaterResources Investigations $84-4253,44 \mathrm{p}$.

30. Lobmeyer, D.H., Whitfield, M.S., Lahoud, R.R., and Bruckheimer, Laura, 1983, Geohydrologic data for Test Well UE-25b\#1 Nevada Test Site, Nye County, Nevada: U.S. Geological Survey Open-File Report $83-855,48 \mathrm{p}$.

31. Maldonado, Florian, and Koether, S.I., 1983, Stratigraphy, structure, and some petrographic features of tertiary volcanic rocks at the USW G-2 drill hole, Yucca Mountain, Nye County, Nevada: U.S. Geological Survey Open-File Report 83-732, 83 p.

32. Mckeown, F.A., and Wilmarth, V.R., 1959, Geology of the Marble Exploration Hole 4, Nevada Test Site, Nye County, Nevada: U.S. Geological Survey Open-File Report TEM-1036, 26 p.

33. Moore, J.E., 1962, Selected logs and drilling records of wells and test holes drilled at the Nevada Test Site prior to 1960: U.S. Geological Survey Open-File Report TEI-804, 54 p.

34. Moore, J.E., Doyle, A.C., Walker, G.E., and Young, R.A., 1963, Ground water Test Well 2, Nevada Test Site, Nye County, Nevada, with a section on Geophysical logs by R.D. Carroll: U.S. Geological Survey Open-File Report TEI-836, $73 \mathrm{p}$.

35. Moore, J.E., and Garber, M.S., 1962, Ground water Test Well B, Nevada Test Site, Nye County, Nevada: U.S. Geological Survey Open-File Report TEI-808, $39 \mathrm{p}$.

36. Orkild, P.P., 1969, Summary geologic report on the U20m emplacement hole, Pahute Mesa, Nevada Test Site: U.S. Geological Survey Report USGS-474-7, $10 \mathrm{p}$. Available only from National Technical Information Service, U.S. Department of Commerce, Springfield, VA 22161.

37. Orkild, P.P., and Jenkins, E.C., 1970, Report of exploration progress, Pahute Mesa January 31, 1968 - October 1, 1969: U.S. Geological Survey Report USGS-474-70, $82 \mathrm{p}$. Available only from National Technical Service, U.S. Department of Commerce, Springfield, VA 22161. 
38. Price, C.E., 1959, "Granite" exploration hole, area 15, Nevada Test Site, Nye County, Nevada--Interim Report, Part B, hydrologic data: U.S. Geological Survey Open-File Report TEM-836-B, 20 p.

39. Price, C.E., and Thordarson, William, 1961, Ground water Test Well A, Nevada Test Site, Nye County, Nevada--a summary of lithologic data, aquifer tests and construction: U.S. Geological survey Open-File Report TEI-800, 59 p.

40. Quinlivan, W.D., Ohl, J.P., and Blackmon, P.D., 1977, Lithologic logs of selected exploratory and emplacement drill holes in areas 2 and 8, Nevada Test Site: U.S. Geological Survey Report USGS-474-227, 80 p. Available only from National Technical Information Service, U.S. Department of Commerce, Springfield, VA 22161.

41. Schoff, S.I., and Moore, J.E., 1964, Chemistry and movement of ground water, Nevada Test Site: U.S. Geological Survey Open-File Report TEI-838, $66 \mathrm{p}$.

42. Spengler, R.W., Beyers, F.M., Jr., and Warner, J.B., 1981, Stratigraphy and structure of volcanic rocks in drill hole USW-Gl, Yucca Mountain, Nye County, Nevada: U.S. Geological Survey Open-File Report 81-1349, $50 \mathrm{p}$.

43. Thordarson, william, 1965, Perched ground water in zeolitized-bedded tuff, Rainer Mesa and vicinity, Nevada Test Site, Nevada: U.S. Geological Survey Open-File Report TEI-862, $90 \mathrm{p}$.

44. ---1983, Geohydrologic data and test results from Well J-13, Nevada Test Site, Nye County, Nevada: U.S. Geological Survey Water-Resources Investigations Report 83-4171, $57 \mathrm{p}$.

45. Thordarson, William, Garber, M.S., and Walker, G.E., 1962, Ground water Test Well D, Nevada Test Site, Nye County, Nevada:

U.S. Geological Survey Open-Eile Report TEI-803, 58 p.

46. Thordarson, William, Rush, F.E., Spengler, R.W., and Waddell, S.J., 1984, Geohydrologic and drill-hole data for Test Well USW H-3, Yucca Mountain, Nye County, Nevada: U.S. Geological Survey Open-File Report 84-149, 28 p.

47. Thordarson, William, Rush, F.E., and Waddell, S.J., 1985, Geohydrology of test well USW H-3, Yucca Mountain, Nye County, Nevada: U.S. Geological Survey Water-Resources Investigations Report $84-4272,38 \mathrm{p}$.

48. Thordarson, William, Young, R.A., and Winograd, I.J., 1967, Records of wells and test holes in the Nevada Test site and vicinity (through December 1966): U.S. Geological survey Open-File Report TEI-872, 26 p.

49. U.S. Geological Survey, 1971, Geologic and hydrologic effects evaluation and safety program, Bahia (U20p) event: U.S. Geological Survey Report USGS-474-126, $28 \mathrm{p}$. Available only from National Technical Information Service, U.S. Department of Commerce, Springfield, VA 22161 .

50. ---1973, Geologic and hydrologic effects prediction and effects program, Almendro (U19v) event, Pahute Mesa, Nevada Test Site: U.S. Geological Survey Report USGS-474-163, $38 \mathrm{p}$. Available only from National Technical Information Service, U.S. Department of Commerce, Springfield, VA 22161. 
51. Waddell, R.K., 1982, Two-dimensional, steady-state model of groundwater flow, Nevada Test Site and vicinity, Nevada-California: U.S. Geological Survey Water-Resources Investigations Report $82-4085,72 \mathrm{p}$.

52. ----1985, Hydrologic and drill-hole data for test wells UE-29a\#1 and UE-29a\#2, Fortymile Canyon, Nevada Test Site: U.S. Geological Survey Open-File Report 84-142, 25 p.

53. Waddell, R.K., Robison, J.H., and Blankennagel, R.K., 1984, Hydrology of Yucca Mountain and vicinity, Nevada-California--investigative results through mid-1983: U.S. Geological Survey Water-Resources Investigations Report 84-4267, $72 \mathrm{p}$.

54. Walker, G.E., 1962, Ground water in the Climax Stock, Nevada Test Site, Nye County: U.S. Geological Survey Open-File Report TEI-813, $48 \mathrm{p}$.

55. Weir, J.E., Jr., and Hodson, J.N., 1979, Geohydrology of Hole UE-17a, Syncline Ridge area, Nevada Test Site: U.S. Geological Survey report USGS-1543-4, $18 \mathrm{p}$.

56. Weir, J.E., Jr., and Meyer, G.L., 1970, Geohydrology of the U20f emplacement chamber, Pahute Mesa, Nevada Test Site, with a section on Geology by D.L. Hoover: U.S. Geological Survey Report USGS$474-60,25$ p. Available only from National Technical Information Service, U.S. Department of Commerce, Springfield, VA 22161.

57. Weir, J.E., Jr., and Nelson, J.W., 1976, Operation and maintenance of a deep-well water-level measurement device, the "iron horse": U.S. Geological Survey Water-Resources Investigations Report $76-27,28 \mathrm{p}$.

58. Whitfield, M.S., Jr., Eshom, E.P., Thordarson, William, and Schaefer, D.H., 1985, Geohydrology of rocks penetrated by test well USW H-4, Yucca Mountain, Nye County, Nevada: U.S. Geological Survey WaterResources Investigations Report 85-4030, $33 \mathrm{p}$.

59. Whitfield, M.S., Thordarson, William, and Eshom, E.P., 1984, Geohydrologic and drill-hole data for Test Well USW H-4, Yucca Mountain, Nye County, Nevada: U.S. Geological Survey Open-File Report 84-449, 39 p.

60. Williams, V.S., 1986, Computer generation of geologic cross sections and derivative maps, Nevada Test Site: Third Symposium on the Containment of Underground Nuclear Explosions, Idaho Falls, Idaho, September 1985, Proceedings, v. 2, p. 85-98

61. Wilmarth, V.R., Healey, D.I., Clebsch, Alfred, Jr., Winograd, I.J., Zietz, Isidore, and Oliver, H.W., 1959, A summary interpretation of geologic, hydrologic, and geophysical data for yucca valley, Nevada Test Site, Nye County, Nevada: U.S. Geological Survey open-File Report TEI-358, 53 p.

62. Winograd, I.J., and Thordarson, William, 1975, Hydrogeologic and hydrochemical framework, south-central Great Basin, NevadaCalifornia, with special reference to the Nevada Test Site: U.S. Geological Survey Professional Paper 712-C, 126 p. 


\section{BASIC DATA}

$-11-$ 

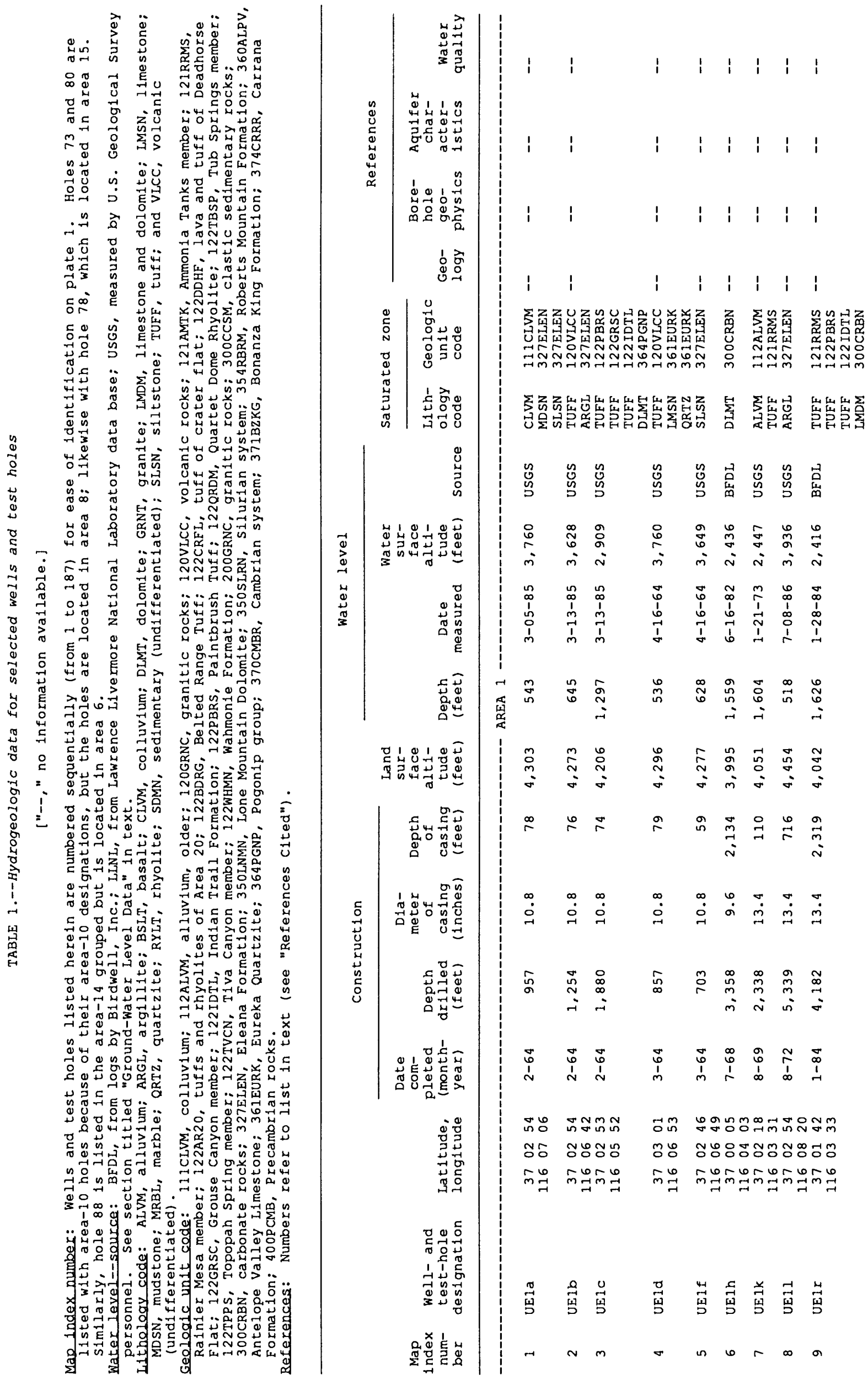

号

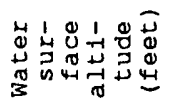

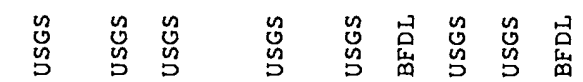

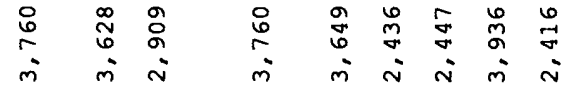

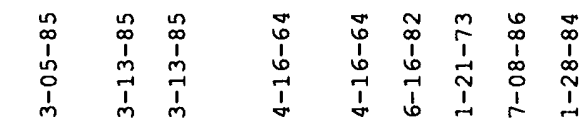

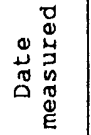

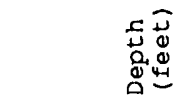

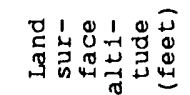

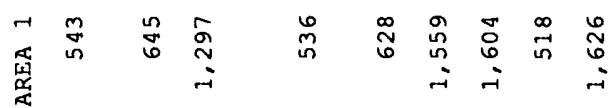

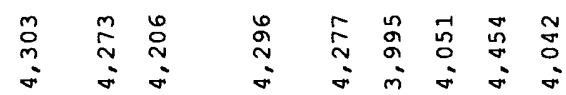

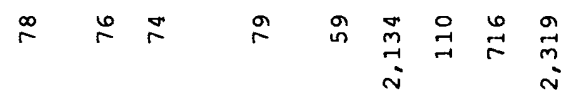

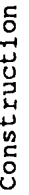

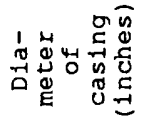

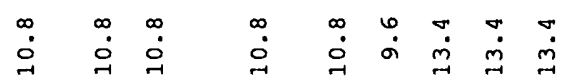

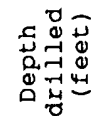

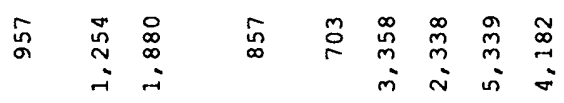

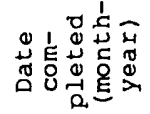

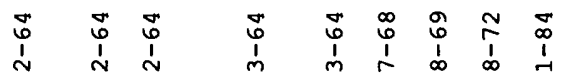

离芦

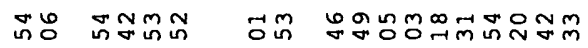

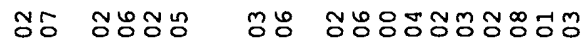

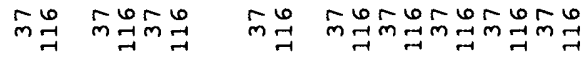

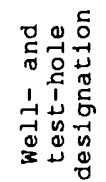

要总晨崖

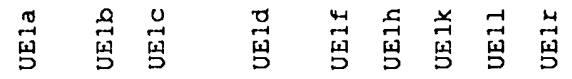




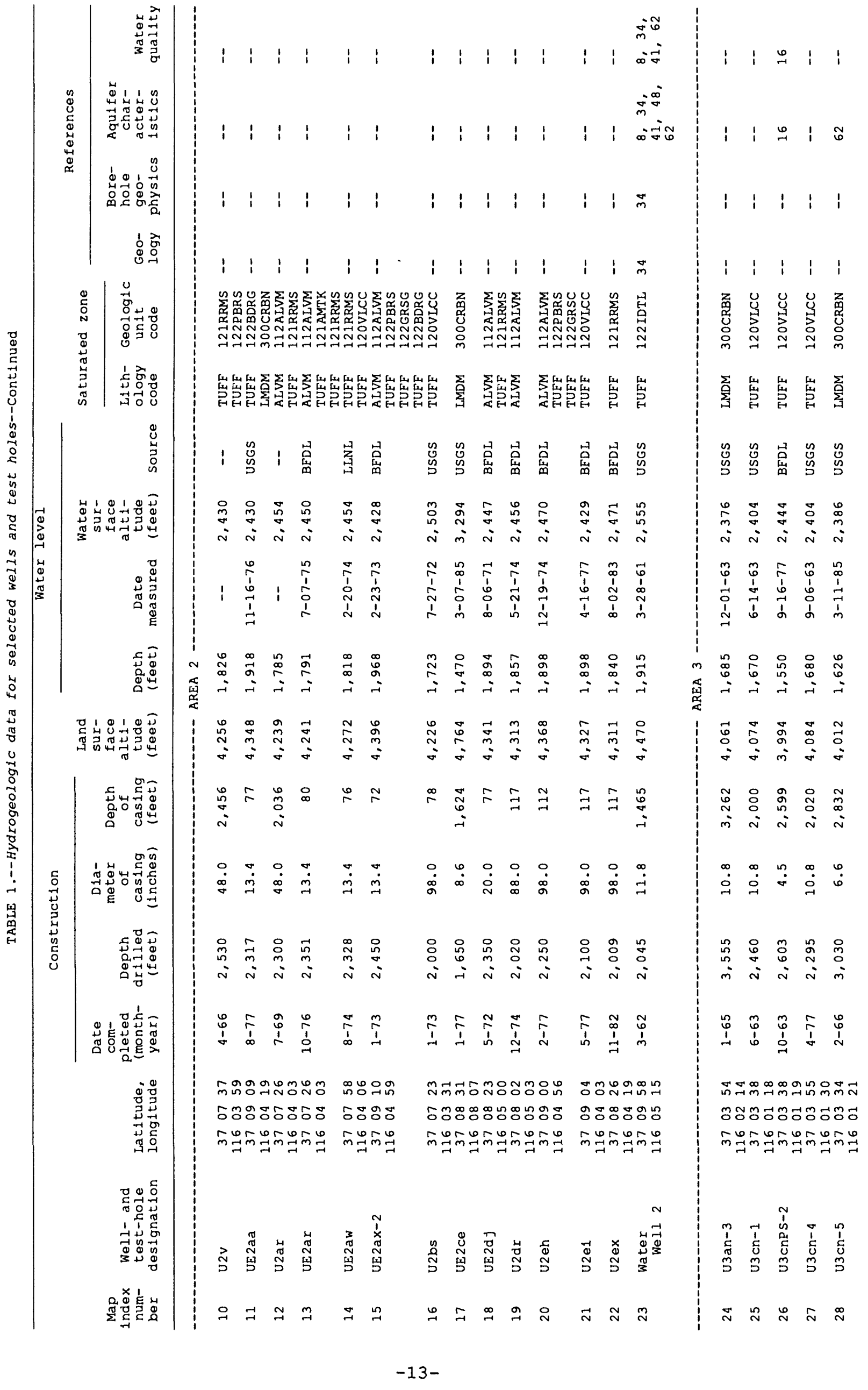




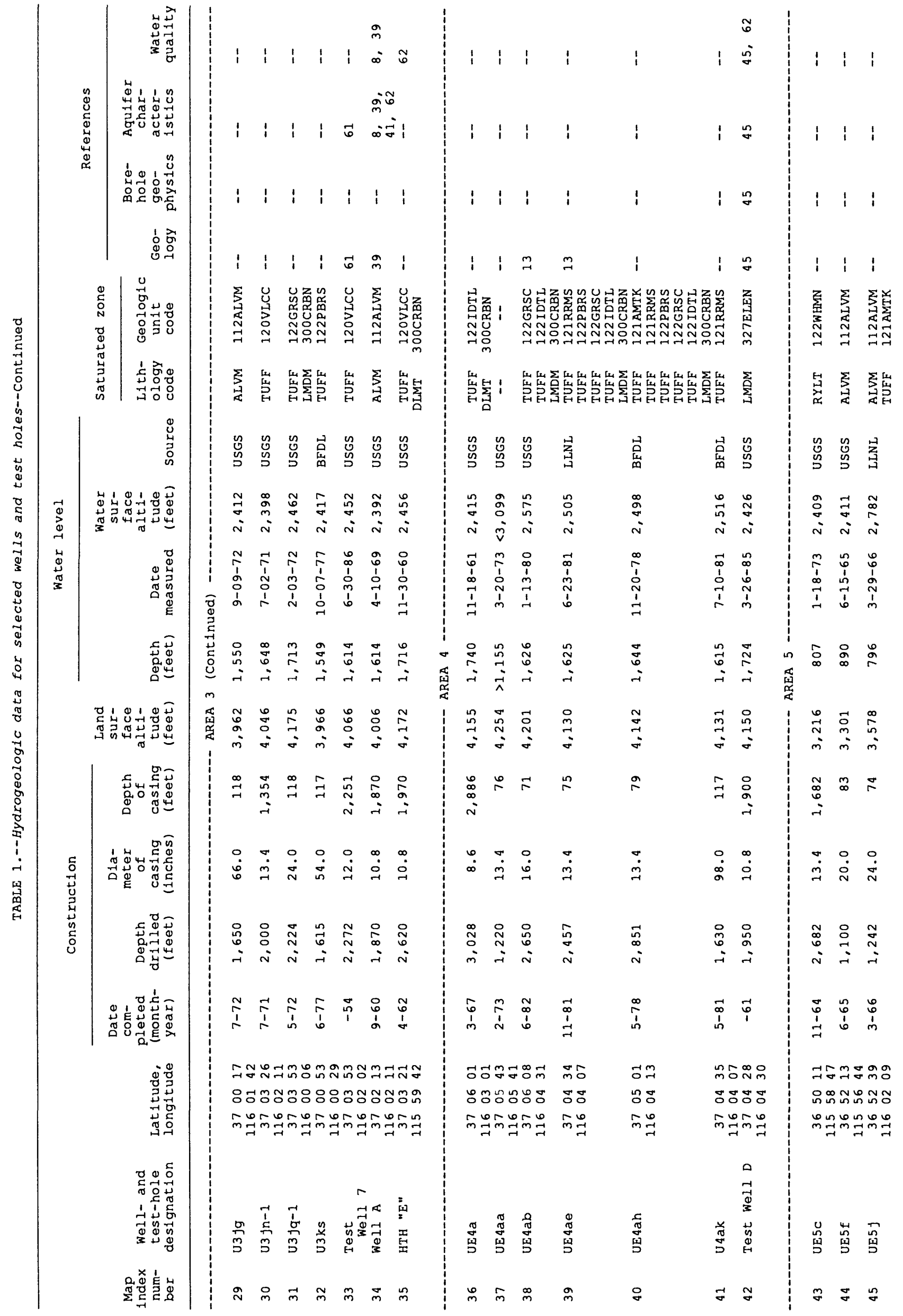




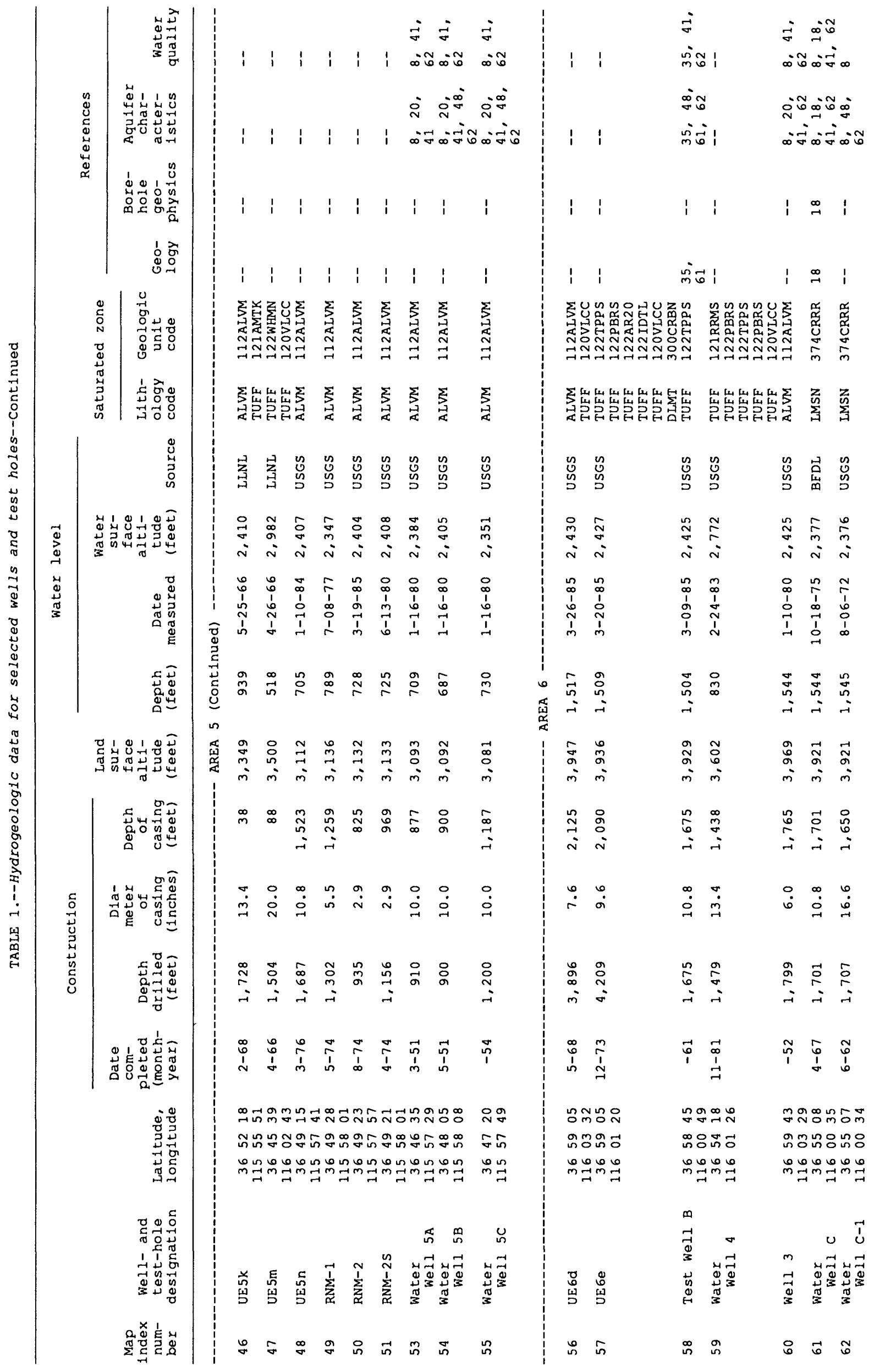




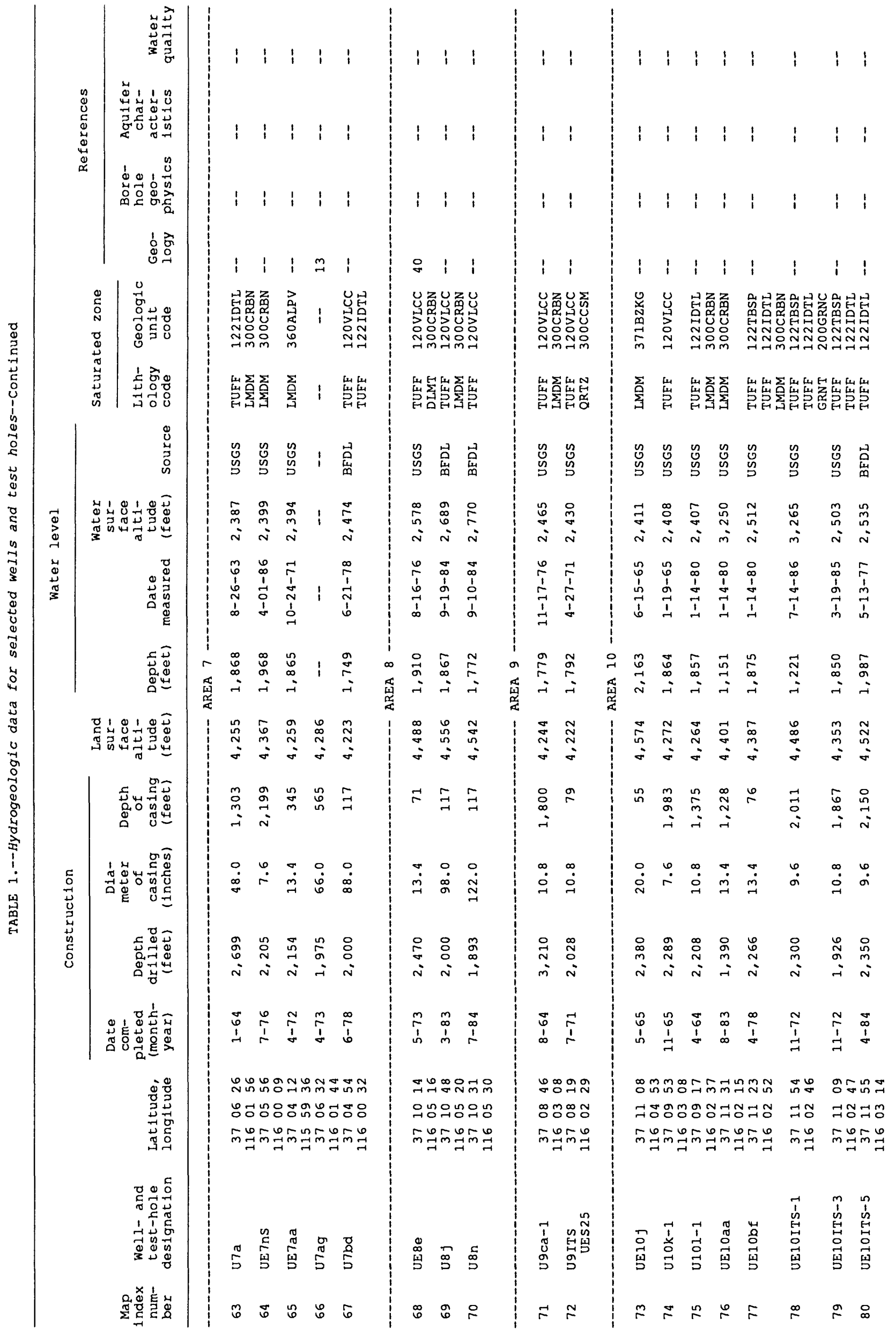




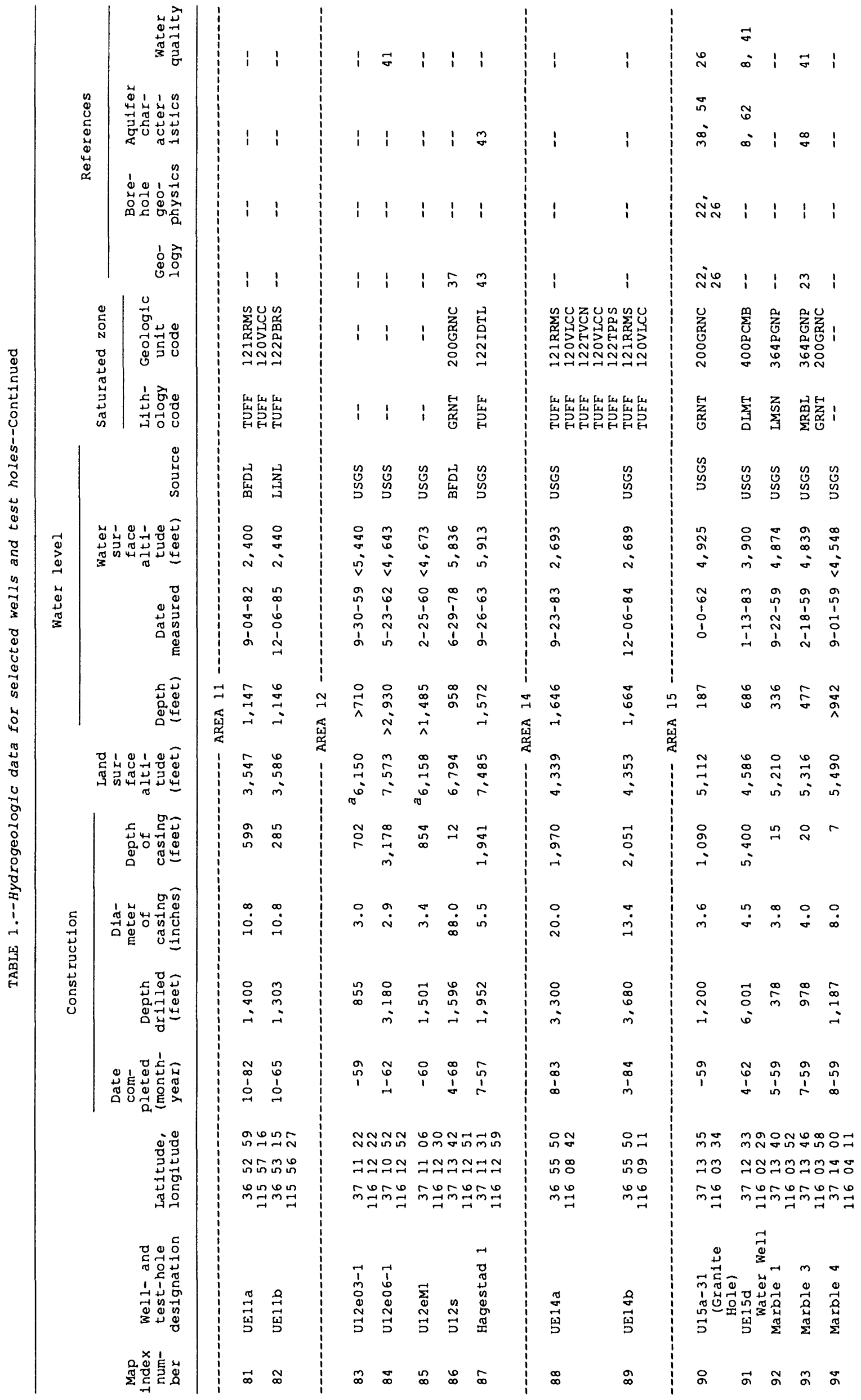









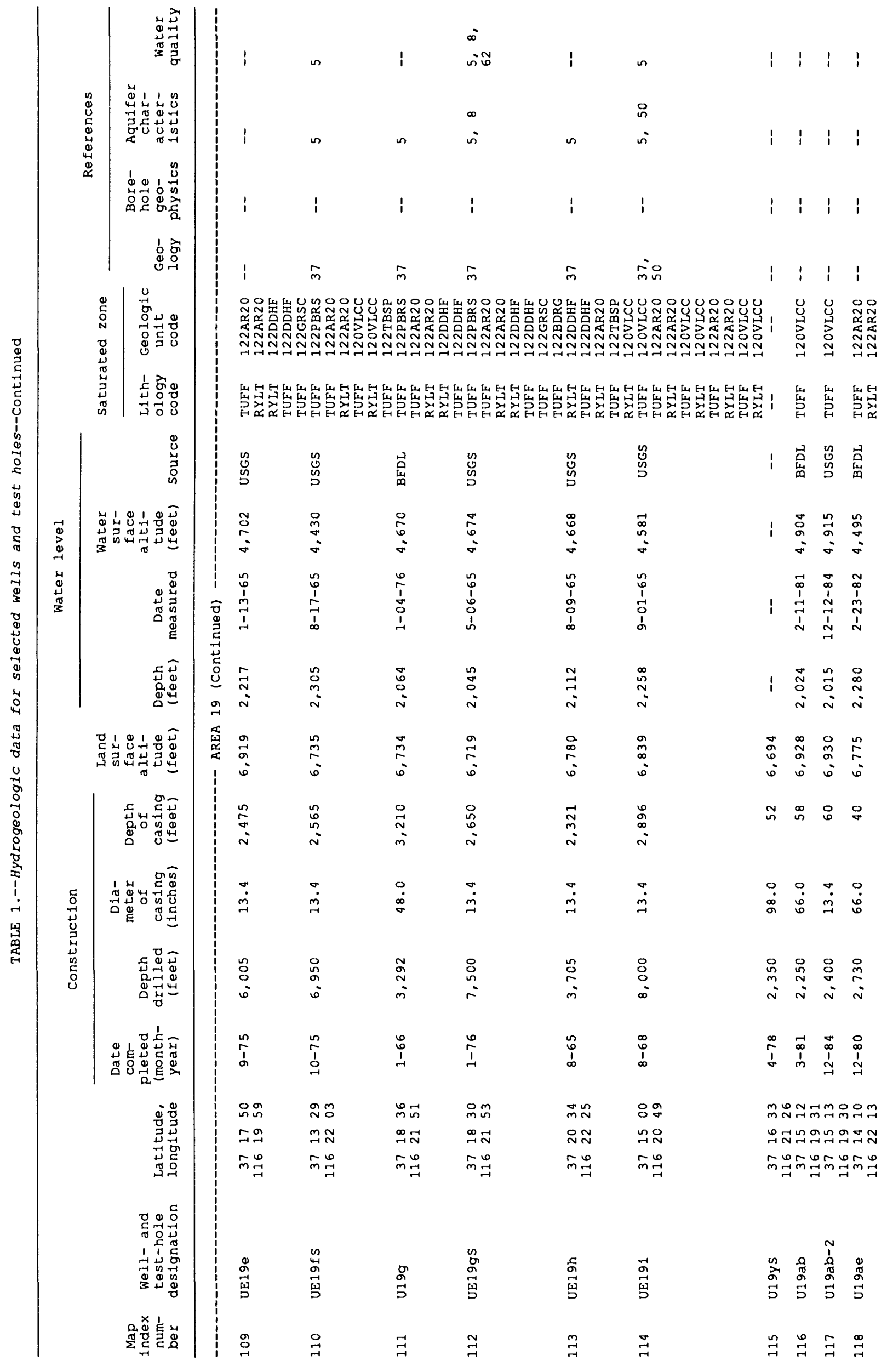




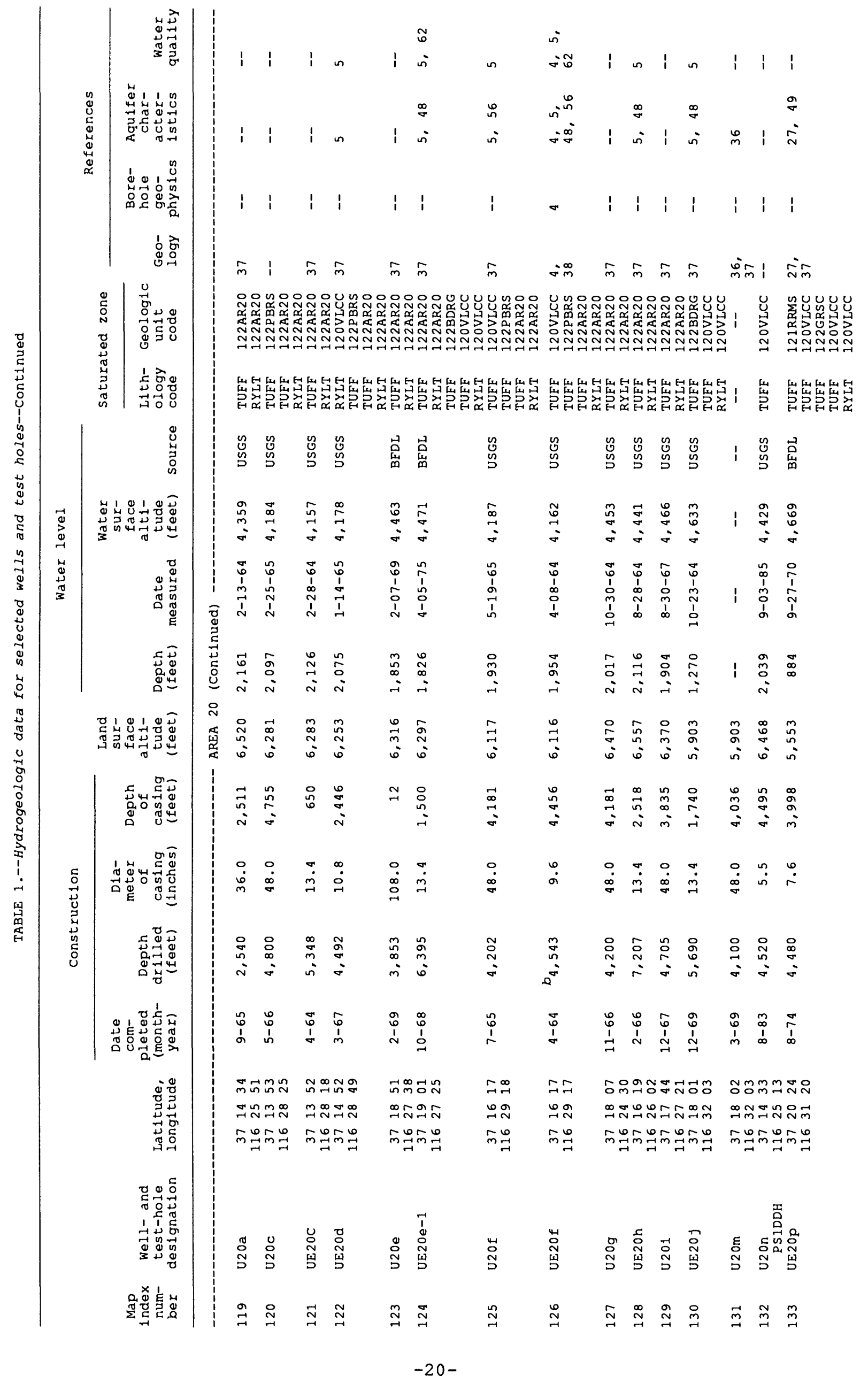




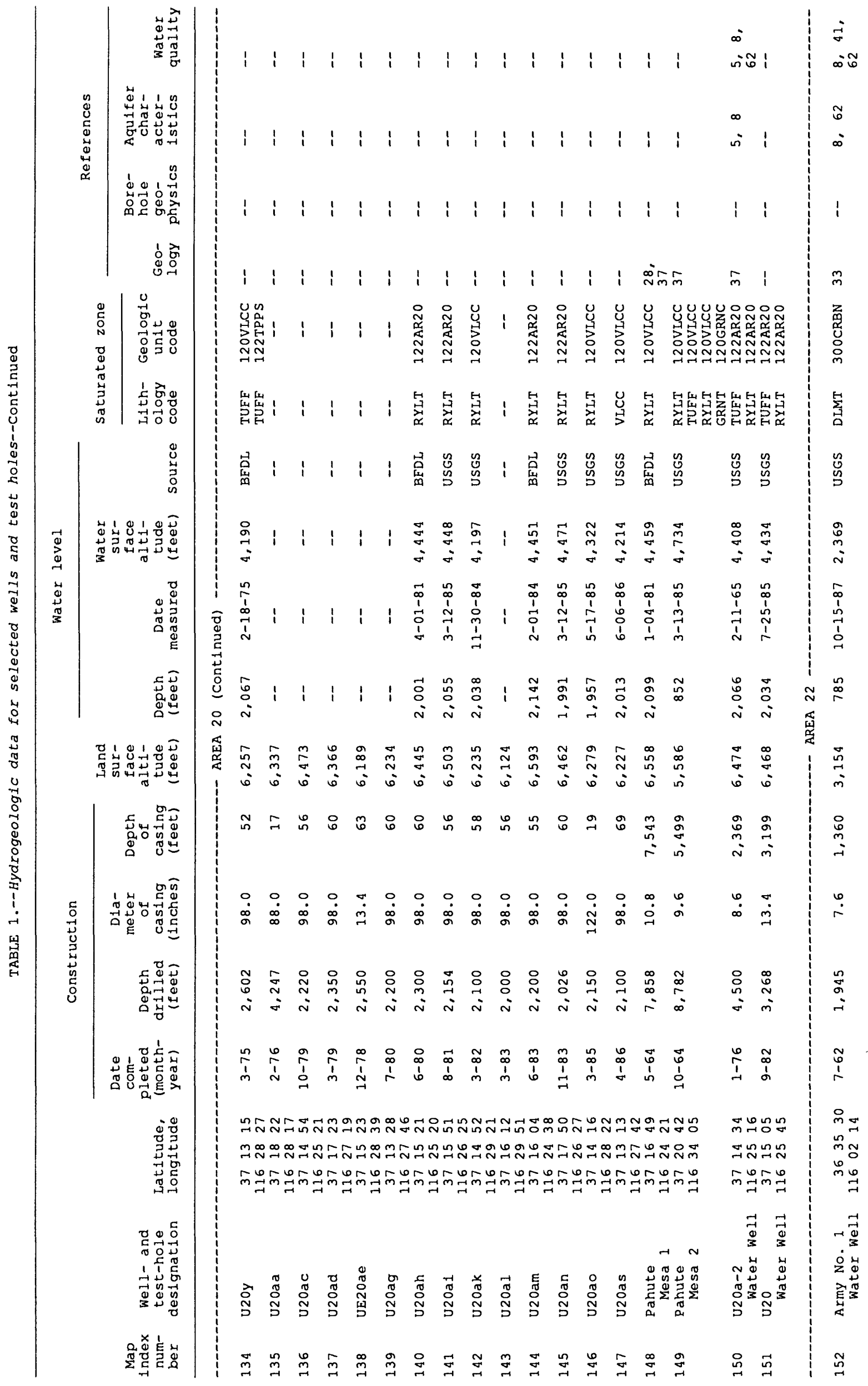




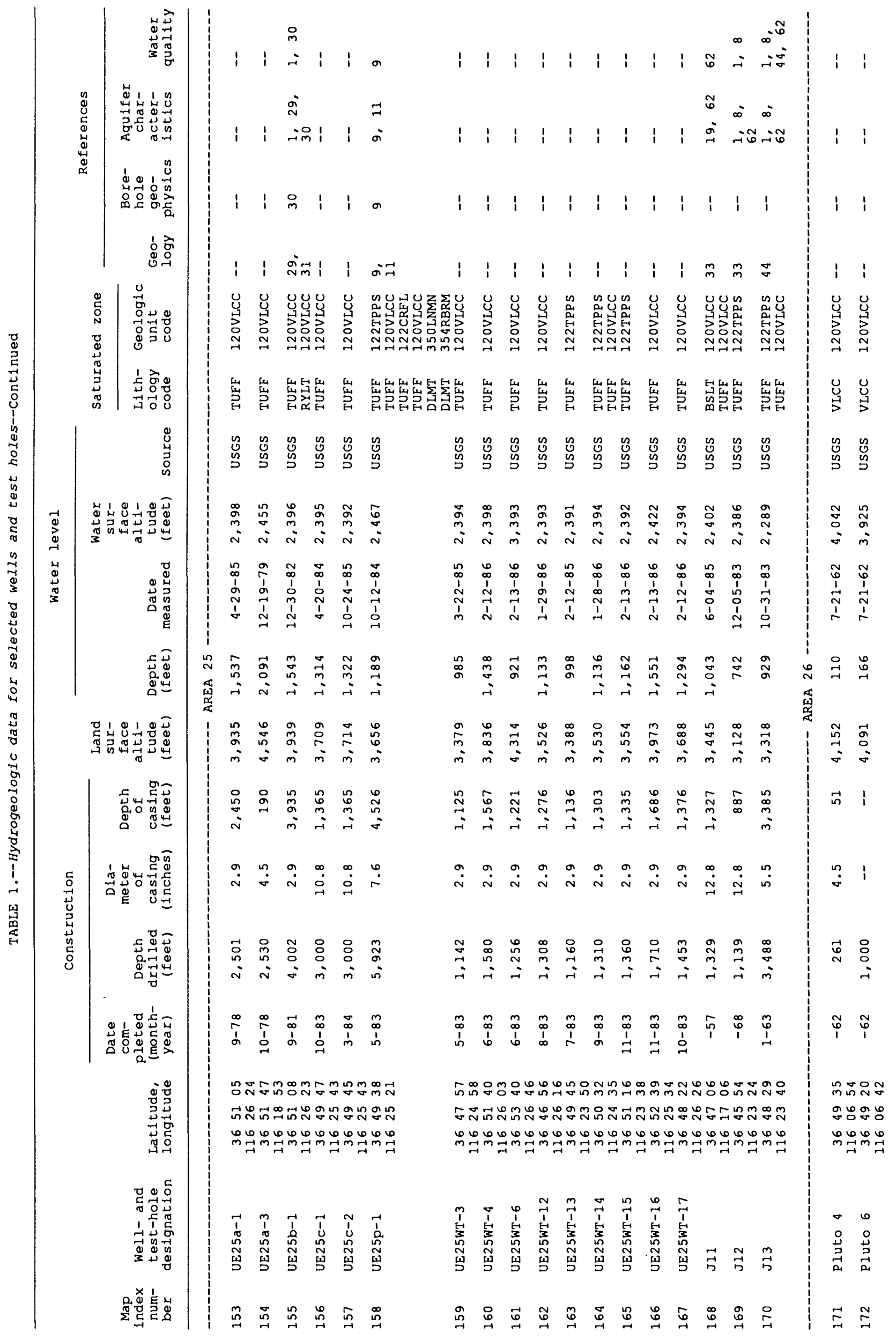




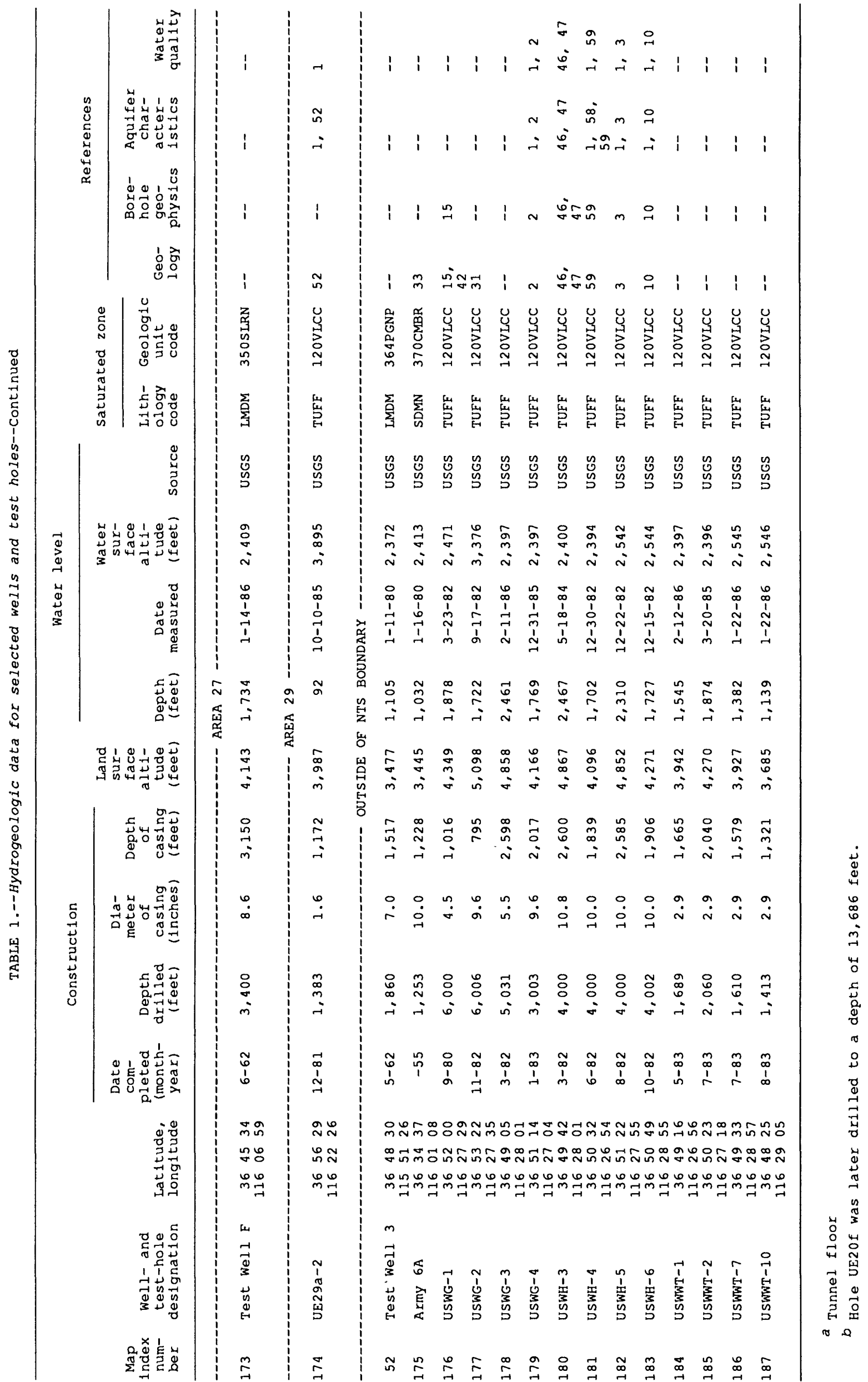

